\begin{tabular}{|l|l|l||}
\hline \multicolumn{2}{|c|}{ PublisherInfo } \\
\hline \hline PublisherName & $:$ & BioMed Central \\
\hline \hline PublisherLocation & $:$ & London \\
\hline \hline PublisherImprintName & $:$ & BioMed Central \\
\hline \hline
\end{tabular}

\title{
Proof of trans-splicing
}

\begin{tabular}{|l|l|l||}
\hline \multicolumn{2}{|c|}{ ArticleInfo } \\
\hline \hline ArticleID & $:$ & 4180 \\
\hline \hline ArticleDOI & $:$ & $10.1186 /$ gb-spotlight-20010817-01 \\
\hline \hline ArticleCitationID & $:$ & spotlight-20010817-01 \\
\hline \hline ArticleSequenceNumber & $:$ & 251 \\
\hline \hline ArticleCategory & $:$ & Research news \\
\hline ArticleFirstPage & $:$ & 1 \\
\hline \hline ArticleLastPage & $:$ & 2 \\
\hline \hline & & RegistrationDate : 2001-08-17 \\
ArticleHistory & $:$ & OnlineDate $\quad$ 2001-08-17 \\
\hline \hline ArticleCopyright & $:$ & BioMed Central Ltd2001 \\
\hline \hline ArticleGrants & $:$ & \\
\hline \hline ArticleContext & $:$ & 130592211 \\
\hline \hline
\end{tabular}


It has been proposed that isoforms of Drosophila $\bmod (\operatorname{mdg} 4)$ result from the trans-splicing of independent mRNA transcripts derived from both anti-parallel DNA strands. In the August 14 Proceedings of the National Academy of Sciences, Rainer Dorn and researchers at the Martin Luther University, Halle, Germany, provide proof for trans-splicing of $\bmod (\mathrm{mdg} 4)$ transcripts in transgenic flies (Proc Natl Acad Sci USA 2001, 98:9724-9729). They characterized 26 different classes of $\bmod (m d g 4)$ transcripts all containing a common 5' sequence (exons 1-4). Analysis of $\bmod (\operatorname{mdg} 4)$ isoforms and the entire $28 \mathrm{~kb} \bmod (\operatorname{mdg} 4)$ locus provided further evidence for trans-splicing of mRNA from both strands. To prove the splicing phenomenon formally, Dorn et al. generated transgenic flies expressing tagged $\bmod (m d g 4)$ exons from different chromosomal loci. The presence of spliced transcripts was confirmed using RT-PCR analysis. They also found evidence for independent, isoform-specific promoters. This study provides an interesting animal system to investigate the mechanisms of trans-splicing in vivo.

\section{References}

1. Protein encoding by both DNA strands

2. Proceedings of the National Academy of Sciences, [http://www.pnas.org]

3. Martin Luther University, [http://www.uni-halle.de] 